\title{
MASYARAKAT DESA ADAT TENGANAN PEGRINGSINGAN
}

\author{
Dyah Respati Suryo Sumunar, Suparmini, dan Sriadi Setyawati \\ Fakultas Ilmu Sosial Universitas Negeri Yogyakarta \\ email: dyah_respati@uny.ac.id
}

\begin{abstract}
Abstrak: Masyarakat Desa Adat Tenganan Pegringsingan. Tujuan penelitian ini untuk mengetahui kondisi lingkungan fisik dan sosial kemasyarakatan Desa Adat Tenganan Pegringsingan, serta cara masyarakat Desa Adat Tenganan Pegringsingan dalam mengelola lingkungan. Penelitian ini merupakan penelitian deskriptif dengan pendekatan kualitatif dengan melakukan pengamatan dan wawancara dengan beberapa tokoh masyarakat, kepala desa, kepala adat, dan anggota masyarakat. Hasil penelitian menunjukkan bahwa letak Desa Tenganan berada pada kawasan perbukitan dengan topografi kasar. Pemukiman Tenganan dibagi menjadi tiga Banjar adat, yaitu Banjar Kauh, Banjar Tengah, dan Banjar Kangin. Banjar Kangin disebut juga Banjar Pande, yang dibagi lagi menjadi dua pemukiman, yaitu Pande Kaja dan Pande Kelot. Masyarakat tradisional Bali Aga di Desa Tenganan masih sangat menjunjung tinggi adat istiadat dari leluhur yang dilaksanakan secara turun temurun, termasuk dalam pengelolaan kawasan dan lingkugannya. Masyarakat Desa Tenganan menjunjung tinggi Ajaran Tri Hita Karana yang merupakan salah satu ajaran dalam agama Hindu yang pada intinya mengajarkan tentang keseimbangan antara manusia dengan Tuhan, manusia dengan manusia, dan manusia dengan lingkungannya.
\end{abstract}

Kata kunci: masyarakat tradisional, Bali Aga, Tenganan, pengelolaan lingkungan

\section{TRADITIONAL AND INDIGENOUS SOCIETY OF TENGANAN PEGRINGSINGAN}

\begin{abstract}
Traditional and Indigenous Society of Tenganan Pegringsingan. This study was aimed at determining the physical environment condition, social condition, and the environmental management of Tenganan Pegringsingan. This study is descriptive qualitative research. The data were collected through observation and interview with several community leaders, village heads, customary heads, and community members of Tenganan Pegrisingan Village. The results show that the location of Tenganan Village is in the hilly area with rough topography. Tenganan settlement is divided into three Banjar adat, namely Banjar Kauh, Banjar Tengah, and Banjar Kangin. Banjar Kangin is also called Banjar Pande, which is divided into two settlements, namely Pande Kaja and Pande Kelot. The Balinese Aga traditional community in Tenganan village still highly upholds the customs of ancestors carried out from generation to generation, including in the area and environmental management. The people of Tenganan village uphold the Tri Hita Karana Teachings which is one of the teachings in Hinduism which essentially teaches about the equality between man and God, man with man, and man with his environment.
\end{abstract}

Keywords: traditional society, Bali Aga, Tenganan, environmental management 


\section{PENDAHULUAN}

Upaya pelestarian sumber daya alam senantiasa berhubungan secara langsung dengan nilai dan tingkah laku penduduk lokal. Karena itu, sungguh ironis apabila interaksi penduduk lokal dengan lingkungannya kerap kali diabaikan dalam upaya pelestarian alam. Selain itu, pada banyak kasus di berbagai negara berkembang dalam upaya pelestarian alam banyak konflik dengan penduduk lokal. Hal tersebut antara lain dikarenakan pada umumnya kegiatan pelestarian alam dilakukan secara over-protective terhadap kehidupan liar, mengingat para penyusun konsep pelestarian alam dari ahli Barat mengasumsikan bahwa perkembangan kemajuan sosial ekonomi masyarakat negara-negara berkembang sama dengan perkembangan kemajuan negara industri Barat.

Mengingat pentingnya peranan masyarakat lokal dalam pelestarian alam, maka tak heran apabila pada KTT Bumi di Rio de Janeiro tahun 1992 telah dimunculkan wacana tentang 'konservasi tradisional', yang berlandaskan pada kearifan budaya tradisional, berupa praktik-praktik pemanfaatan sumber daya alam oleh masyarakat lokal yang masih terikat pada pranata-pranata lokal yang menyatu dalam keseharian hidupnya (Wiratno, dkk., 2001: 163).

Dalam pengelolaan kawasan konservasi alam, seyogianya selain aspekaspek biofisik, perlu pula diperhatikan aspek sosial, ekonomi dan budaya masyarakat lokal, termasuk praktik pelestarian kawasan suci atau sakral oleh masyarakat lokal. Sesungguhnya isu tentang pelestarian daerah suci, daerah sakral, atau daerah keramat dalam kaitan pelestarian alam telah mendapat perhatian UNESCO, dengan menjadikannya sebagai suatu kawasan Cagar Biosfer.
Di Indonesia, dikenal beberapa daerah yang disakralkan dan disucikan oleh masyarakat lokal, antara lain hutan keramat (HK) di Kampung Dukuh, Garut Selatan; HK di Kampung Naga, Tasikmalaya; HK Gunung Halimun Masyarakat Kasepuhan, Sukabumi Selatan, dan HK di Kawasan Baduy, Banten Selatan. Pada umumnya, berbagai kawasan hutan keramat tersebut masih terpelihara cukup baik oleh masyarakat lokal. Padahal berbagai kawasan hutan di Jawa Barat dan Banten, di luar kawasan hutan keramat tersebut telah banyak yang mengalami kerusakan parah (Iskandar, 2016). Oleh karena itu, berbagai kawasan hutan keramat tersebut mempunyai fungsi penting bagi pelestarian keanekaragaman hayati yang ada di dalamnya.

Keberadaan kawasan hutan dikeramatkan hampir merata pada berbagai etnik Nusantara. Kelompok masyarakat mengakui adanya nilai-nilai tidak terukur, nilai-nilai magis di balik fenomena alam hutan. Eksistensi kelompok masyarakat berkembang mengikuti dua pola dasar. Pertama, pola alamiah. Masyarakat berdasarkan pengalamannya berinteraksi dengan lingkungannya dan mereka mengakui adanya kekuatan gaib yang mempengaruhi hidupnya. Kedua, masyarakat lokal berinteraksi dengan kelompok masyarakat pendatang dan mendapat pengetahuan tentang kekuatan magis dalam kehidupannya serta memiliki landasan sistem norma (Suryadarma, 2017: 50-56).

Di Provinsi Bali, di antara beberapa desa adat yang ada, yakni Desa Adat Bali Aga Tenganan atau yang lebih dikenal dengan Desa Adat Tenganan Pegringsingan, di Kecamatan Manggis, Kabupaten Karangasem sampai saat ini masih memelihara dan melestarikan kawasan dan lingkungannya menyatu dengan masyarakatnya yang terikat dalam 
tata aturan yang disebut dengan Tri Hita Karana (THK). Dengan THK tersebut, segala tata aturan dikelola, diikuti, dan ditaati dengan baik sehinga kawasan dan lingkungan di Desa Adat Tenganan Pegringsingan senantiasa lestari.

Interaksi antara manusia dan lingkungannya tidak selalu berdampak positif, ada kalanya menimbulkan dampak negatif, yakni dengan munculnya bencana, malapetaka, dan kerugian-kerugian lainnya. Pada kondisi seperti itu, kearifan lokal yang dimiliki oleh masyarakat dapat meminimalkan dampak negatif yang ada atau dengan kata lain, mitigasi bencana atau pengurangan resiko terhadap bencana dapat dilakukan melalui keraifan lokal yang ada pada masyarakat setempat. (Sumunar, dkk., 2013: 739-751). Demikian juga pada masyarakat Desa Adat Tenganan Pegringsingan dengan mengikuti, melaksanakan, dan menyakini awig-awig (undang-undang) yang dilakukan secara turun temurun, secara sadar atau tidak sadar, langsung atau tidak langsung, dan hal itu merupakan wujud kearifan lokal yang dimilikinya mempunyai peranan yang besar terhadap upaya mitigasi bencana.

Bali sebagai destinasi pariwisata nasional yang menyediakan berbagai fasilitas pariwisata dan berbagai keunikan budayanya, menjadikan Bali salah satu sentra pariwisata di Republik Indonesia. Tidak dapat dipungkiri, Bali menerima terpaan arus globalisasi. Wisatawan mancanegara maupun domestik dipesonakan oleh keindahan alam dan budaya Bali. Fasilitas-fasilitas kepariwisataan berlomba-lomba membuat terobosan yang bertujuan untuk menarik wisman (wisatawan mancanegara). Oleh karena itu, disesuaikanlah rumah-rumah tradisional di Bali dengan selera para wisman. Implikasi dan implementasinya yaitu pada fungsi spasial bangunan pada permukiman tradisional (Mendra \& Wiriantari, 2016: 73-97).

Oleh karena itu, pengelolaan kawasan dan lingkungan pada masyarakat Desa Adat Tenganan Pegringsingan dengan berbagai kearifan budaya tradisional, sangat penting dan menarik untuk dikaji. Berdasarkan permasalahan yang telah diuraikan di atas, penelitian ini difokuskan pada pengamatan terhadap pengelolaan kawasan dan lingkungan Desa Adat Tenganan Pangringsingan, di Kecamatan Manggis, Kabupaten Karangasem, Provinsi Bali.

\section{METODE}

Penelitian ini didesain sebagai penelitian deskriptif dengan pendekatan kualitatif. Hasil penelitian ini berusaha untuk menjelaskan secara rinci mengenai keadaan yang ada di lapangan. Dalam penelitian ini, variabel yang diamati adalah (1) kondisi fisik lingkungan masyarakat Desa Adat Tenganan Pegringsingan; (2) kondisi sosial, ekonomi, budaya masyarakat Desa Adat Tenganan Pegringsingan; (3) kearifan lokal masyarakat Desa Adat Tenganan Pegringsingan; dan (4) pengelolaan kawasan dan lingkungan dalam masyarakat Desa Adat Tenganan Pegringsingan.

Masyarakat Desa Adat Tenganan Pegringsingan pada umumnya menjadi subjek dalam penelitian ini. Beberapa narasumber atau key informan diperlukan dalam pemerolehan data dan informasi. Peneitian dilaksanakan pada bulan Mei 2016 di Desa Adat Tenganan Pegringsingan, Kecamatan Manggis, Kabupaten Karangasem, Provinsi Bali.

Dalam mengumpulkan data penelitian, digunakan teknik observasi, dokumentasi, dan wawancara. Teknik observasi yang dilakukan yaitu observasi terstruktur, peneliti sudah menyiapkan pedoman observasi. Instrumen observasi 
menggunakan daftar isian atau chek list. Metode dokumentasi digunakan untuk melengkapi data dan informasi lain yang diperoleh dari instansi terkait atau sumber referensi lain, termasuk studi pustaka. Lembar dokumentasi digunakan sebagai instrumen dalam penelitian ini. Wawancara merupakan suatu metode pengumpulan data atau fakta di lapangan. Prosesnya dapat dilakukan secara langsung dengan bertatap muka langsung (face to face) dengan narasumber atau key informan. Pedoman wawancara digunakan sebagai instrumen untuk memudahkan dalam proses wawancara dengan nara sumber atau key informan.

Analisis data dalam penelitian ini menggunakan tiga alur kegiatanyang terjadi secara bersamaan yaitu: reduksi data, penyajian data, penarikan kesimpulan/ verifikasi. Reduksi data diartikan sebagai proses pemilihan, pemusatan perhatian pada penyederhanaan, pengabstakan, dan transformasi data "kasar" yang muncul dari catatan-catatan tertulis di lapangan. Reduksi data merupakan bagian dari analisis. Reduksi data merupakan suatu bentuk analisis yang menajamkan, menggolongkan, mengarahkan, membuang yang tidak perlu, dan mengorganisasi data dengan cara sedemikian rupa hingga kesimpulan-kesimpulan finalnya dapat ditarik dan diverifikasi. Penyajian data sebagai sekumpulan informasi tersusun yang memberi kemungkinan adanya penarikan kesimpulan dan pengambilan tindakan. Penarikan kesimpulan, hasil analisis ditampilkan secara kualitatif dengan bentuk narasi.

\section{HASIL DAN PEMBAHASAN Gambaran Umum}

Desa Tenganan terletak di Kecamatan Manggis, Kabupaten Karangasem, Provinsi Bali dengan luas wilayah 917,218 ha. Desa Tenganan atau dikenal dengan Tenganan
Pegringsingan, merupakan salah satu dari sejumlah desa adat masyarakat Bali Aga yang ada di Pulau Bali. Iklim di Desa Tenganan adalah tropis, dengan curah hujan rata-rata $1.500-2000 \mathrm{~mm} /$ tahun dan temperatur berkisar antara $28-30^{\circ} \mathrm{C}$. .

Penduduk Desa Adat Tenganan Pegringsingan hingga tercatat berjumlah 232 kepala keluarga (KK) atau \pm 670 jiwa. Umumnya masih berpendidikan SD dan SMP. Namun, sudah banyak juga warga Tenganan Pegringsingan yang mengenyam pendidikan tinggi dan meraih gelar sarjana. Aktivitas keseharian warga Tenganan Pegringsingan yakni bertani atau pun menekuni usaha kerajinan.

Desa Tenganan merupakan sebuah desa yang masih sangat konservatif dalam menjaga warisan leluhur mereka. Desa Tenganan merupakan salah satu Desa di kawasan Bali yang tidak terdapat kasta, karena kasta merupakan suatu budaya yang dibawa oleh kerajaan orang Hindu Jawa yaitu dari Kerajaan Majapahit. Warga Desa Tenganan mengutamakan keseimbangan dalam berbagai hal. Hal ini sesuai dengan ajaran yang dianut mereka yaitu Hindu Darma Sekte Indra yang disebut Tri Hita Karana yang menyatakan bahwa untuk menjaga hubungan keseimbangan antara manusia dengan manusia, manusia dengan alam, dan manusia dengan Tuhan. Meskipun demikian, di Desa Tenganan terdapat struktur sosial adat berupa 10 golongan yang membedakan peran seseorang terhadap desa dan tugas pokok fungsi masing-masing, tetapi tidak menjadikan adanya pembeda tingkat status sosial antargolongan. Golongangolongan tersebut yakni Sanghyang, Ngijeng, Batu Guling Mage, Batu Guling, Empak Buluh, Prajurit, Pande Mas, Pande Besi, Pasek, dan Bendesa.

Pada berbagai Banjar yang ada di Desa Tenganan terdapat berbagai macam golongan yang tersebut di atas. Semua 
golongan dapat menjadi pemimpin adat, karena kepemimpinan terbentuk berdasarkan senioritas pernikahan. Tetapi dalam golongan ini hanya dapat dimiliki oleh keturunan saja. Pernikahan antargolongan diperbolehkan dan jika terjadi, golongan seorang perempuan dan anak akan mengikuti golongan lakilakinya (suami) sehingga yang mengalami perubahan golongan hanya pihak perempuan karena di Desa Tenganan menggunakan sistem patrilinear.

Penduduk Desa Tenganan Pegringsingan belum merata secara ekonomi. Hal ini terbukti bahwa masih ada penduduk yang masuk kategori miskin. Sebagian besar mata pencaharian masyarakat di Desa Tenganan sebagai petani dalam arti luas, di samping mata pencaharian lainnya seperti pedagang, penjual jasa, dan sebagainya. Dalam rangka meningkatkan hasil pertanian, masyarakat banyak mendapatkan pembinaan dari instansiinstansi terkait melalui kelompokkelompok seperti kelompoktani, kelompok ternak, dan kelompok pengrajin. Adapun hasil pertanian utama adalah buah kelapa yang dikembangkan dari hasil kebun rakyat. Di samping itu, juga ada tanah pertanian yang dikerjakan penggarap. Sedangkan hasil ternak yaitu babi, kerbau, dan ayam.

Perekonomian masyarakat selain dari pertanian juga berasal dari kegiatan menjual hasil kerajinan berupa kain gringsing yang harganya mahal, karena pengerjaannya memerlukan waktu yang lama. Ada pula masyarakat yang menjual kerajinan lain berupa kerajinan dari bambu, lukisan pada daun lontar, dan sebagainya.

Ciri khas Desa Tenganan yakni kain tenun ikat yang disebut kain gringsing. Oleh karena itu, nama desa ini lebih dikenal dengan Desa Tenganan Pegringsingan. Menurut pandangan orang Tenganan, kain gringsing mengandung nilai magis. Hal ini dikatakan demikian karena kata gringsing berasal dari dua kata yaitu gering yang berarti "sakit" atau "penyakit" dan sing berarti "tidak" atau "menolong". Dan kedua akar kata tersebut yaitu kata gering dan sing disatupadukan akan menjadi kata gringsing yang dapat berarti tidak sakit atau menolak penyakit yang dapat diperkirakan akan terhindar dari segala penyakit.

Orang Tenganan mempunyai pandangan bahwa kain gringsing memiliki peranan atau fungsi yang amat penting sebagai bagian dari kehidupan adat mereka. Kain ini sering digunakan pada saat diadakan upacara adat. Dalam pandangan masyarakat Desa Tengananan, kain tenun gringsing memiliki nilai magis dan membutuhkan waktu yang cukup lama dalam pembuatannya, kain gringsing tidak hanya dibuat oleh golongan tertentu saja, tetapi semua orang atau golongan yang mau belajar dan bisa membuat tenunan kain gringsing diperbolehkan membuat kain tenun gringsing yang memiliki nilai magis bagi masyarakat Desa Tenganan tersebut. Keahlian ini didapat secara turun temurun dari nenek moyang mereka. Kain gringsing dibuat dengan cara ditenun dan waktu pembuatannya pun cukup lama. Pembuatan satu lembar kain gringsing memerlukan waktu 6 bulan sampai 2 tahun, bergantung pada ukuran kain yang dibuat.

Dalam masyarakat Tenganan, kain gringsing ini boleh dipakai oleh siapa saja tanpa membedakan status sosial orang. Selain itu, yang memakai kain gringsing tidak dibatasi usia, dari anak-anak sampai orang dewasa boleh memakainya. Akan tetapi, kain gringsing ini hanya dibuat oleh para perempuan saja. Hal ini dikarenakan perempuan sebagian besar waktunya di rumah, sedangkan laki-laki bekerja di sawah. Di dalam keterkaitannya antara 
kain gringsing dan stratifikasi sosial, kain gringsing tidak mencerminkan status sosial orang yang memakainya. Semua dianggap sama oleh masyarakat Tenganan, meskipun harga kain gringsing itu jutaan rupiah. Ini juga diperkuat oleh masyarakat Desa Tenganan yang tidak menganut sistem kasta.

Secara umum, setiap keluarga pada masyarakat Desa Tenganan harus melaksanakan ritual tebenan sesuai dengan urutan-urutan atau tata cara yang berlaku, tidak ada pembedaan antara masyarakat yang mempunyai kelas ekonomi tinggi atau seseorang yang dipandang mempunyai kedudukan khusus dalam masyarakat. Setiap keluarga melaksanakan upacara tebenan sesuai dengan aturan- aturan adat yang ada. Perbedaan upacara yang dilaksanakan tertetak pada besar kecilnya acara yang dilaksanakan berdasarkan tingkat perekonomian mereka.

Ritual atau upacara adat yang dilakukan oleh masyarakat Desa Tenganan berikutnya adalah upacara perkawinan. Sistem perkawinan yang dianut oleh masyarakat Desa Tenganan adalah sistem parental, perempuan dan laki-laki dalam keluarga memiliki derajat yang sama dan berhak menjadi ahli waris. Hal ini berbeda dengan sistem kekeluargaan yang dianut oleh masyarakat di Bali pada umumnya. Di samping itu, mereka juga menganut sistem endogamy, masyarakat setempat terikat dalam awig-awig (hukum adat) yang mengharuskan pernikahan dilakukan dengan sesama warga Desa Tenganan. Apabila dilanggar, warga tersebut tidak diperbolehkan menjadi krama (warga) desa. Artinya, ia harus keluar dari Desa Tenganan dan secara fisik suami-isteri akan dihukum buang (maselong) untuk beberapa lama ke tempat yang jauh dari tempat asalnya. Semenjak tahun 1951, hukum semacam itu tidak pernah dijalankan lagi. Saat ini perkawinan campuran dengan orang luar desa sudah relatif lebih banyak dilaksanakan.

Bentuk perkawinan yang dianggap pantang adalah perkawinan bertukar antara saudara perempuan suami dengan saudara laki-laki istri (makedeng-anngad), karena perkawinan yang demikian itu dianggap mendatangkan bencana (panes). Di beberapa daerah di Bali (tidak semua daerah), berlaku pula adat penyerahan mas kawin (patuku luh), tetapi sekarang adat ini terutama di antara keluargakeluarga orang-orang terpelajar sudah menghilang. Serangkaian tata cara upacara perkawinan tersebut harus dilakukan oleh semua masyarakat Desa Tenganan tanpa memandang status sosial individu tersebut dalam masyarakat, kewajiban, dan tanggung jawab nilainilai sosial. Dalam upacara perkawinan ini yang membedakan hanyalah tingkat perekonomian masing-masing keluarga yang akan berpengaruh terhadap skala upacara perkawinan yang dilaksanakan.

Ritual atau upacara adat lainnya yang dilakukan oleh masyarakat Desa Tenganan adalah upacara kematian atau biasa disebut dengan luanan. Seseorang yang mati pada masyarakat Desa Tenganan diletakan di Bale tengah (Madia Mandala), bale ini biasa disebut Bale Duluan. Seseorang yang mati pada Masyarakat Desa Tenganan akan dikuburkan pada makam adat setempat dalam kondisi telanjang bulat. Hal ini sesuai dengan filosofi yang dianut oleh masyarakat Desa Tenganan bahwa mereka lahir dalam keadaan telanjang bulat (tanpa pakaian dan segala macam unsur duniawi), maka mati pun mereka akan kembali dalam keadaan tanpa busana dan unsur duniawi pula. Dalam pelaksanaan upacara kematian, semua masyarakat harus menjalani serangkaian proses ritual sesuai dengan yang letah ditentukan dalam adat yang berlaku, tidak ada pengkhususan ritual tertentu 
untuk golongan masyarakat tertentu. Seluruh sistem ritual kematian ini harus dilaksanakan oleh masyarakat tanpa terkecuali, satu-satunya faktor yang pembeda dalam pelaksanaan upacara kematian adalah tingkat perekomonian keluarga.

\section{Perkembangan Wilayah dan Pemerin- tahan}

Pada sekitar abad VIII pada zaman Adat Bali ada pemerintahan yang disebut manca, antara lain Manca Nyuhtebel, Manca Tenganan, Manca Manggis. Kirakira 1906 manca-manca tersebut di atas dihapuskan digantikan dengan istilah Perbekel, di Tenganan ada perbekel yang pertama memimpin di Desa yang secara berturut-turut dijabat oleh I Karti (alm) (tahun 1933-1940). Sejak di bawah pemerintahan I Karti, Desa Tenganan terdiri dari tiga Desa Adat yaitu Desa Adat Tenganan Pegringsingan, Desa Adat Tenganan Dauh Tukad, dan Desa Adat Gunung. Di samping itu, masing-masing desa adat tersebut memiliki wilayah yang terkecil di lingkungan pemerintahan desa yaitu dusun/lingkungan. Desa Tenganan terdiri atas lima dusun yaitu Dusun Tenganan Pegringsingan, Dusun Tenganan Dauh Tukad, Dusun Bukit Kangin, Dusun Gumung, dan Dusun Bukit Kauh.

Kemudian I Karti digantikan oleh I Nengah Suji (alm) (tahun 1941-1952). Pada saat itu pemerintahan berjalan seperti biasanya, karena memang dari sebelumnya pelayanan administrasi dilaksanakan di rumah masing-masing sampai terjadinya musibah Gunung Agung meletus. Pada saat itu banyak pengungsi datang dari pelosok Kabupaten Karangasem.

Pemerintahan I Nengah Suji kemudian digantikan oleh I Nyoman Rumi (tahun 1953-1962), kemudian I Nyoman Suarna (tahun 1963-1971). Pemerintahan I
Nyoman Suarna digantikan oleh I Nyoman Pasek (tahun 1972-1982), kemudian diganti oleh I Nyoman Sadra B.A (19831993), kemudian Drs. I Nengah Wartawan (1994-1998), Plt. I Ketut Sudimbia B.A (1990-2001). Berdasarkan hasil pemilihan perbekel, sejak 1 Oktober 2002 dilantik I Putu Suarjana, S.S sebagai Perbekel Desa tenganan Pegringsingan yang menjabat sejak tahun 2002-sampai sekarang dan sekaligus menjadi perbekel Desa Tenganan Pegringsingan.

\section{Pendidikan dan Kesehatan}

Untuk meningkatkan pembangunan di segala bidang, pendidikan mempunyai peran yang utama, karena melalui pendidikan sumber daya manusia dapat digali sekaligus sebagai insan pembangunan dapat ditingkatkan. Seperti orang bijak mengatakan bahwa kebodohan adalah biang keladi kemiskinan dan kemelaratan, maka tepat lah prasejarah Kabupaten Karangasem memberikan segala prioritas terhadap peningkatan mutu di bidang pendidikan, kesehatan, dan pengentasan kemiskinan, yang dituju adalah Karangasem Aman, Damai, Maju, dan Sejahtera. Dalam perkembangan dunia pendidikan, di Desa Tenganan memerlukan perhatian pemerintah dan pihak komite/orang tua murid untuk dapat memberikan Tut Wuri Handayani agar menjadi harapan bersama untuk meningkatkan bidang pendidikan. Serta ikut mensukseskan program pemerintah memberikan informasi kepada masyarakat melalui rapat-rapat Desa guna mengantisipasi anak-anak yang putus sekolah baik di tingkat SD maupun SMP dan memberikan kesempatan kepada anak-anak putus sekolah atau yang tidak, untuk melanjutkan ke sekolah nonformal seperti Kejar Paket B yang sudah dibuka di Banjar Dinas Tenganan Dauh Tukad. 
Dalam rangka peningkatan derajat kesehatan masyarakat dengan adanya SKBM, antisipasi perpaduan antara program pemerintah dengan kesadaran masyarakat sebab tanpa kesadaran masyarakat untuk mengikuti program pemerintah di dalam bidang kesehatan tentu tidak akan terwujud.

Adapun program yang tidak berkembang dalam rangka meningkatkan derajat kesehatan adalah (1) dalam rangka mengurangi resiko terhadap ibu yang akan melahirkan dibentuklah suatu Gerakan Sayang Ibu-Bayi Baru Lahir (GSI-B); (2) untuk mengurangi jika dapat meniadakan kematian bayi akibat kurang gizi, tanpa imunisasi dan sebagainya dibentuklah posyandu, dan (3) air bersih adalah kebutuhan yang paling mendasar serta untuk meningkatkan kesehatan masyarakat memakai air bersih bersumber dari PDAM yang dialirkan melalui sumur bor yang terletak di wilayah Banjar Dinas Tauman, Desa Nyuhtebel dan bak penampungan terletak di Banjar Dinas Kanginan, Desa Pekraman Pesedahan. Di samping itu, penggunaan air bersih yang terlarik dari Tukad Buhu ke Gunung Kaja dengan sistem gravitasi/perpipaan dan ditempuh melalui Bukit Kangin, Bukit Kauh, Banjar Dinas Tenganan Pegringsingan, dan Tenganan Dauh Tukad. Adapun air bersih yang dikonsumsi masyarakat adalah dengan bantuan pemerintah Australia yang dikelola oleh Desa Dinas dengan Wadah UPS-AAB (Unit Pengelolaan Sarana Air Bersih).

\section{Pengelolaan Kawasan dan Lingkungan di Desa Tenganan}

Desa Tenganan terletak pada ketinggian 50 sampai $500 \mathrm{dpl}$, suhu 2830 derajat celcius. Curah Hujan 620 mm/ tahun.

Klasifikasi lahan di Desa Adat Tenganan Pegringsingan adalah sebagai berikut. (1) Hak milik oleh desa/bersama/ komunal disebut Duwen Desa (Laba Pura, Duwen Sekeha) diatur dengan awig-awig. (2) Hak kelola oleh pribadi warga desa (diwariskan), tidak dapat dialihkan kepada orang lain dari luar desa. Hak-hak desa dalam pengelolaan hutan yakni Ngalang, Ngrampang, Ngambeng, dan Ngambang.

Ngalang, hak untuk mengambil hasil hutan/tegal untuk keperluan upacara pada sebuah petak abian yakni: kelapa 7 buah, pisang 5 tandan, pinang 1 ijeng, buah-buahan (Mangga, Wani, Kepundung, Ceroring dan lain-lain) sebanyak 1 kise roras (ukuran kise 12 helai), nangka 1 buah, nenas 9 biji, dan sirih 3 cekel. Ngrampang, hak untuk mengambil hasil hutan/tegal untuk keperluan bahan bangunan milik desa/bersama: kayu lakar, ijuk/duk, lima kakab tiap pohon, pohon pinang, 1 pohon tiap petak abian, bambu, 1 batang a lingseh, dan pohon Kelapa. Ngrambeng, hak untuk mengambil hasil hutan/tegal untuk keperluan upacara seperti Tuak, Durian. Ngrambang, hak untuk menangkap ayam yang masih ada induknya untuk keperluan upacara

\section{Pembagian dan Pemanfaatan Lahan di Desa Tenganan}

Desa Tenganan Pegringsingan mempunyai lahan seluas 917,218 ha yang terdiri atas sawah seluas 255 ha, permukiman dan fasilitas umum seluas 78,23 ha, lahan kering yang terdiri atas hutan dan tegalan seluas 583 ha. Luas permukiman hanya $8 \%$ dari seluruh luas lahan di Desa Tenganan Pegringsingan. Kedudukan tanah Desa Tenganan sangatlah penting dalam hukum adat. Ada dua hal yang menyebabkan tanah memiliki kedudukan yang penting dalam hukum adat yakni: (1) merupakan satu-satunya benda kekayaan yang meskipun mengalami keadaan yang bagaimanapun juga, tetapi masih bersifat tetap dalam keadaannya. (2) 


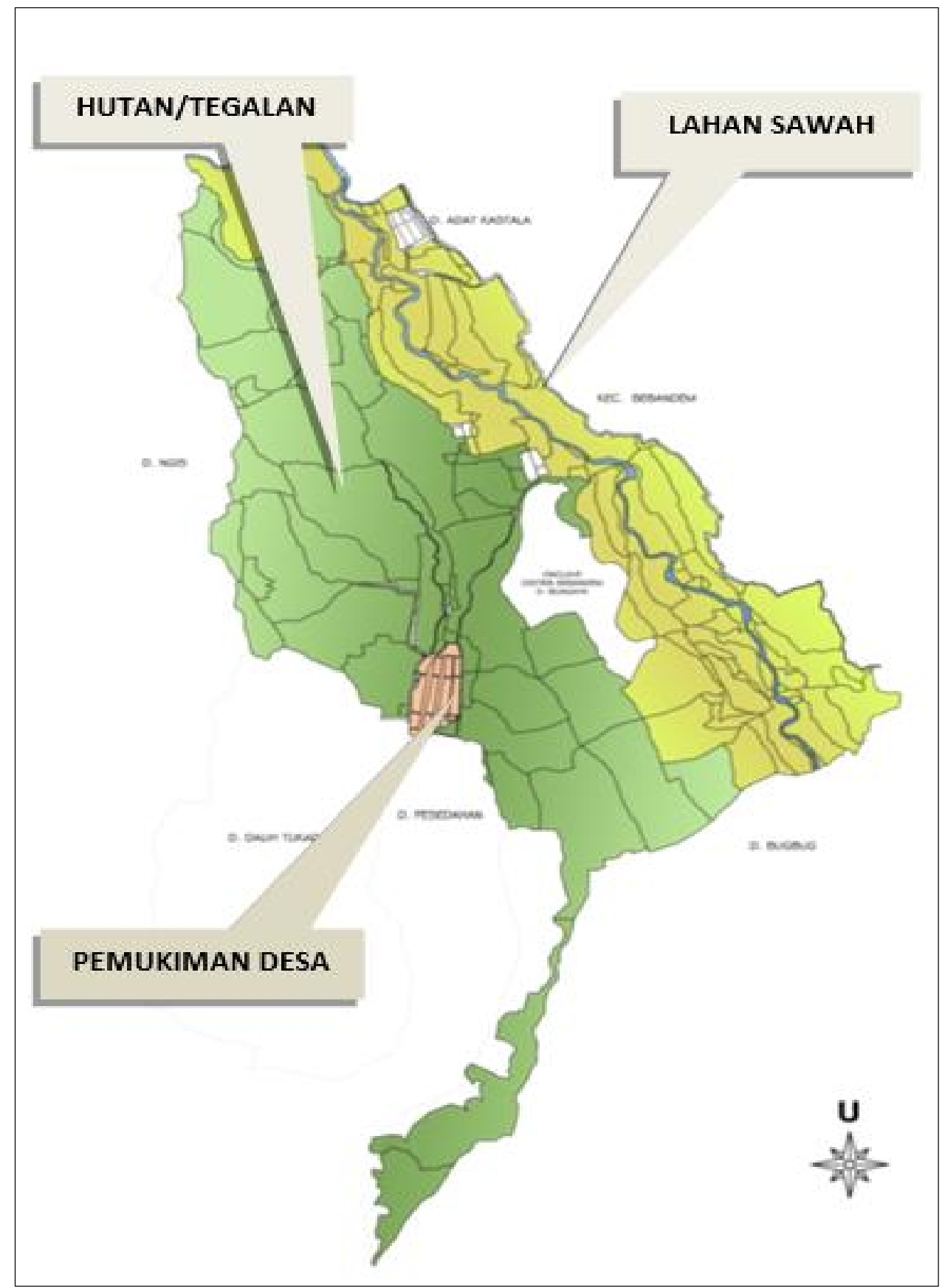

Gambar 1. Pembagian Kawasan di Desa Tenganan

Merupakan tempat tinggal persekutuan, memberikan penghidupan kepada persekutuan, merupakan tempat dimana para warga persekutuan yang meninggal dunia dikebumikan, dan merupakan tempat tinggal kepada dayang-dayang pelindung persekutuan dan roh para leluhur persekutuan.
Antara persekutuan dengan tanah yang didudukinya itu terdapat hubungan yang sangat erat, hubungan yang bersifat religio-magis. Hubungan yang erat dan bersifat religio-magis ini menyebabkan persekutuan memperoleh hak untuk menguasai tanah dimaksud, memanfaatkan tanah tersebut, memungut 


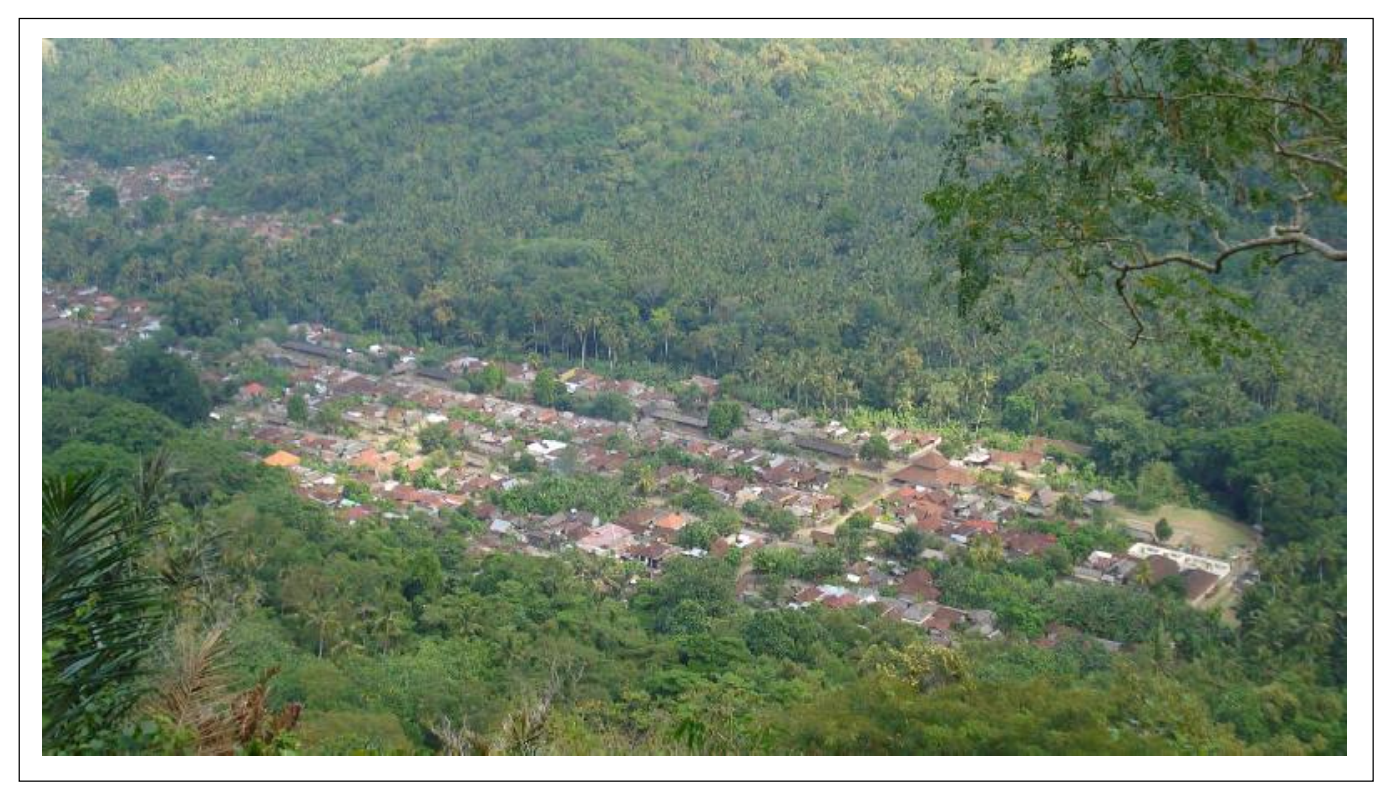

Gambar 2. Kawasan Desa Adat Tenganan Pegringsingan

hasil dari tumbuh-tumbuhan yang hidup di atas tanah tersebut, serta berburu terhadap binatang-binatang yang hidup di tanah tersebut. Hak persekutuan atas tanah disebut hak pertuanan atau hak ulayat, yang menggambarkan tentang hubungan antara persekutuan dan tanah itu sendiri. Objek hak ulayat, yakni: tanah (daratan), air (perairan seperti sungai, danau, pantai), tumbuh-tumbuhan yang hidup secara liar (pohon buah-buahan, pohon-pohon untuk kayu pertukangan atau kayu bakar), dan binatang yang hidup liar.

Adapun cara persekutuan memelihara serta mempertahankan hak ulayatnya yakni Persekutuan berusaha meletakkan batas-batas di sekeliling wilayah kekuasaannya tersebut. Menunjuk pejabat-pejabat tertentu yang khusus bertugas untuk mengawasi wilayah kekuasaan persekutuan yang bersangkutan (pada Desa Adat Tenganan pejabatnya disebut lelipis lembukit).

Kepala Desa Tenganan Pegringsingan yang sempat memberikan penjelasan di balai desa, Putu Yudiana mengatakan bahwa di desa adat tenganan pegringsingan wilayah perkampungan dibuat petakpetak yang sama besar dengan bangunan berbentuk sama pula. Sementara hutan lindung yang mengelilingi perkampungan juga menjadi milik bersama. Semua hasilnya akan menjadi milik adat. Begitu pula tanah pertanian yang tidak bisa menjadi milik pribadi. Status tanah adat di desa tenganan pegringsingan semua milik pihak adat.Kemudian pembagian tanah adat tersebut diberikan kepada sepasang suami istri yang tinggal di desa adat tenganan pegringsingan dan Satu kapling rumah ditempati oleh satu kepala keluarga. Luas petak sama besar, dan bangunannya pun sama, terdiri dari bale meten, bale tengah, bale bunga, dan paon, dan masing masing kepala keluarga yang berhak atas tanah adat tersebut tidak boleh menambah atau mengurangi luas dari tanah adat tersebut. Tanah adat tenganan selain tidak boleh dijual atau digadaikan kepada orang luar, pengelolaan semua tanah berada dibawah kekuasaan desa adat. 
Tanah desa adat yang berupa hak pakai/memanfaatkan dapat dijual asalkan masih dalam lingkup adat tenganan. Misal hak pakai seseorang atas sebidang sawah hasil pencariannya sendiri, yang menurut hukum barat berarti hak mutlak, di dalam hukum adat hak tersebut masih juga terkait dengan kepentingan kekerabatannya. Jika ia akan mentransaksikan sawahnya itu ia harus bermusyawarah dengan keluarga/ kerabatnya, agar tindakannya tidak tercela. Jadi hukum adat tidak membenarkan adanya hak pribadi yang mutlak, untuk kepentingan diri sendiri semata-mata.

\section{Pola Permukiman di Desa Tenganan Pegringsingan}

Pemukiman Tenganan dibagi menjadi tiga Banjar adat, yaitu Banjar Kauh (Barat), Banjar Tengah (Tengah), dan Banjar Kangin (Timur). Banjar Kangin disebut juga Banjar Pande, yang dibagi lagi menjadi dua pemukiman, yaitu Pande Kaja (Utara/ Gunung) dan Pande Kelot (Selatan/laut). Pada masing-masing banjar terdapat dua deretan rumah penduduk, sebelah kiri dan kanan jalan desa (awangan) yang dibangun diatas tanah ulayat desa yang disebut karang desa. Pemukiman di Tenganan menganut pola memusat. Membujur dari arah utara dan semakin merendah ke arah selatan. Masing-masing banjar terdiri dari dua deretan rumah penduduk yang berapat alang-alang dan pintu masuk yang menghadap ke jalan desa. Bangunan adat sebagian besar terletak di tengah-tengah jalan desa. Warga Tenganan hanya diperbolehkan untuk tinggal dan memanfaatkan lahan berdasarkan kesepakatan adat dan awig-awig kitab peraturan adat. Untuk menggunakan rumah dan mengambil hasil hutan akan diputuskan melalui kraman desa atau rapat kolektif para pemimpin desa. Pada bagian barat terletak Banjar Kauh yang merupakan bagian utama dari daerah pemukiman penduduk karena hampir semua bangunan terletak pada bagian ini. Meliputi bangunanbangunan balai agung (balai suci), balai petemu (balai pertemuan), balai kul kul (menara kentongan), pawon desa (dapur desa), pawon teruna (dapur pemuda), wantilan (gedung pertemuan), balai jineng (lumbung padi), dan bale kencan (tempat bersantai). Selain itu, pada bagian awangan sebelah barat terdapat bangunan-bangunan khusus milik desa.

Bale Agung, fungsi utamanya sebagai tempat sangkepan (pertemuan) krama desa, baik setiap hari maupun pada saat upacara. Selain itu, juga sebagai tempat penyimpanan inventaris desa seperti selunding (gamelan). Bale Banjar, merupakan bale suci yang hanya digunakan untuk sesuatu hal yang bersifat sakral dan dilarang digunakan untuk pertemuan yang bersifat halangan atau kematian. Bale Kenca, berfungsi sebagai tempat membicarakan suatu perkara penting yang mengarah kepada jalannya persumpahan secara adat. Bale Patemon, merupakan balai pertemuan yang berjumlah tiga buah. Posisinya berderet di sebelah utara bale agung. Bale patemon ini dipakai sebagai tempat pertemuan untuk organisasi pemuda.

\section{Penerapan Tri Hita Karana dalam Upaya Konservasi Hutan di Desa Tenganan}

Konsep Tri Hita Karana telah diterapkan dalam upaya konservasi hutan di Desa Tenganan Pegringsingan terutama bagian Palemahan. Desa Adat Tenganan Pegringsingan mempunyai aturanaturan untuk menjaga kelestarian hutan. Aturan tersebut terdapat dalam awigawig, diantaranya adalah aturan tentang larangan menebang pohon sembarangan. Masyarakatdi Desa Tenganan Pegringsingan tidak diperbolehkan menebang pohon sembarangan meskipun pohon tersebut 
milik sendiri. Setiap pohon yang akan ditebang untuk bahan bangunan mesti melalui rapat desa terlebih dahulu. Bila rapat desa memutuskan pohon itu boleh ditebang, baru bisa dilakukan. Bila pohon masih dalam keadaan berdaun (hidup), warga yang ingin menebang pohon mesti meminta pemeriksaan kepada Kelian Desa. Selanjutnya, Kelian Desa mengutus tiga orang untuk memeriksa pohon tersebut. Komposisi pemeriksa itu, seorang dari Bahan Luanan, seorang dari Bahan Duluan/Keliang Desa serta seorang dari Bahan Tebenan. Pohon boleh ditebang bila hasil pemeriksaan menyebutkan 80 persen dari pohon itu sudah mati hanya 20 persen masih hidup serta bukan poros kayu utama. Namun, harus disetujui oleh ketiga pihak tersebut. Jika salah satu pihak/bahan tidak menyetuhi maka penebangan ditangguhkan beberapa bulan lagi. Namun, dibolehkan menebang pohon bila diperuntukkan untuk membuat fasilitas umum.

Hak tumapung merupakan hak istimewa yang diberikan kepada seseorang yang baru kawin. Menurut aturan di desa ini, tiga bulan setelah upacara pernikahan, sang pengantin mesti berpisah dari orangtuanya dan membangun rumah tangga baru. Pihak desa memberikan keluarga baru itu kapling tanah seluas 2,432 are. Untuk membangun rumah di atas tanah itu, si pengantin dibolehkan menebang pohon kayu tetapi hanya secukupnya.

Desa Adat Tenganan Pegringsingan juga melarang empat macam buah-buahan yang tidak boleh dipetik pemiliknya, baik milik desa atau pun milik perorangan. Keempat buah-buahan itu yakni durian, pangi, kemiri dan tehep. Hanya jika buah itu jatuh boleh diambil. Itu pun bukan harus pemiliknya yang boleh mengambil, siapa pun pun boleh mengambil, khususnya siapa yang datang dan rajin mencari, itulah yang berhak. Bila memotong pohon larangan seperti nangka, cempaka, durian, kemiri, pangi, teep, jaka (aren) di sebelah barat sungai dan di utara desa, kayu tersebut di-daut (diambil) kembali dan harus dibayar seharga kayu ditambah dengan denda. Bila orang dari luar desa memungut empat buah yang dilarang didenda 10 catu (setara dengan 25 kilogram beras). Bila memetik didenda 10 catu (setara 25 kilogram beras) ditambah harga buah yang dipetik. Denda-denda tersebut akan didistribusikan dengan perhitungan, 50 persen ke desa dan 50 persen lagi diberikan untuk si pelapor. Identitas si pelapor juga dirahasiakan.

Berkaitan dengan keletarian flora, warga di Desa Adat Tenganan Pegringsingan tidak diperkenankan menjual atau memberikan ijuk kepada orang lain. Akan tetapi, bila menjual tali ijuk dibolehkan. Larangan ini bertujuan untuk tidak mengganggu kehidupan pohon enau sebagai penghasil ijuk. Sementara pohon enau sendiri menjadi tanaman pokok di hutan Tenganan.

Warga Tenganan Pegringsingan juga dilarang membuat arak dan gula. Namun, bila membuat tuak atau air nira dibolehkan. Membuat batu bata merah pun tak diperkenankan. Larangan ini dimaksudkan untuk mencegah penggunaan kayu api yang berlebihan. Namun, yang cukup unik, awig-awig Desa Tenganan Pegringsingan juga melarang warganya menanam pohon tarum. Padahal, tarum merupakan bahan yang digunakan untuk mewarnai kain gringsing khususnya warna biru. Karena itu, warga Tenganan Pegringsingan mesti mencari pohon tarum ini ke luar desa. Makna larangan tidak boleh menanam pohon tarum itu agar warga Tenganan Pegringsingan mau bekerja sama dengan warga luar desa.

Secara lebih rinci, berikut awig-awig yang mengatur tentang pengelolaan hutan 
di Desa Tenganan Pegringsingan. (1) Tidak boleh menebang pohon dengan sehendak hati, tidak boleh menebang pohon yang masih hidup. Apabila melanggar dikenakan sanksi berupa denda uang sebesar 400 kepeng, dan kayu yang ditebang disita oleh adat. (2) Pohon boleh ditebang untuk keperluan bangunan atau untuk kayu api setelah pohon tersebut mati. (3) Pohon yang sudah mati, jika ingin dipotong harus dilaporkan kepada desa adat, yang kemudian memerika kebenarannya. (4) Jenis pepohonan yang dilarang untuk ditebang mislanya kemiri, tehep, durian, cempaka, enau, pangi dan nangka. (5) Dengan alasan tertenu, misalnya karena menghalangi tumbuhnya pohon lain, atau jaraknya terlalu dekat dengan pohon lain, pohon-pohon yang terlarang tersebut boleh ditebang setelah mendapat ijin dari krama adat. (6) Penenbangan pohon yang masih hidup pada tanah sendiri boleh dilakukan untuk keperluan bahan bangunan rumah bagi keluarga yang baru menikah. Hal ini disebut dengan Tumapung. Penebangan boleh dilakukan dengan persetujuan desa adat. (7) Penebangan pohon utuk keperluan desa seperti untuk memperbaiki pura, boleh dilakukan dengan pertimbangan krama adat tanpa mempertimbangkan kondisi tumbuhan dan kepemilikan (rampangan). (8) Buah-buahan tidak boleh dipetik dari pohonnya. Buahnya hanya boleh diambil jika sudah jatuh dari pohonnya. Hal ini berlaku baik pohon buah tersebut terletak dalam tanah pribadi maupun dalam tanah desa. Bagi yang melanggar dikenakan $25 \mathrm{~kg}$ beras ditambah dengan harga dari buah yang dipetik. Denda tersebut 50\% diserahkan ke desa adat, dan 50\% diserahkan ke pelapor yag identitasnya dirahasiakan. (8) Tidak boleh menjual/ menggadaikan tanah ke luar desa. Bagi yang melangar tanah tersebut akan disita oleh desa adat.

\section{SIMPULAN}

Masyarakat Desa Adat Tenganan merupakan salah satu dari masyarakat asli Bali atau disebut sebagai masyarakat "Bali Aga”, yang tinggal di Bali pada kawasan perbukitan. Pemukiman Tenganan dibagi menjadi tiga Banjar adat, yaitu Banjar Kauh (sebelah barat), Banjar Tengah (sebelah Tengah), dan Banjar Kangin (sebelah Timur). Banjar Kangin disebut juga Banjar Pande, yang dibagi lagi menjadi dua pemukiman, yaitu Pande Kaja (Utara/ gunung) dan Pande Kelot (Selatan/laut) Masyarakat Tradisional Bali Aga di Desa Tenganan masih sangat menjunjung tinggi adat istiadat dari leluhur yang dilaksanakan secara turun temurun, termasuk dalam pengelolaan kawasan dan lingkugannya. Masyarakat Desa Tenganan menjunjung tinggi Ajaran Tri Hita Karana yang merupakan salah satu ajaran dalam agama Hindu yang pada mengajarkan tentang keseimbangan antara manusia dengan Tuhan, manusia dengan manusia, dan manusia dengan lingkungannya. Sebagai masyarakat tradisional, kearifan lokal masih sangat kentara dan kearifan lokal yang berupa ajaran dan aturan sangat dipegang teguh, bahkan dijadikan dasar dalam menalani kehidupan seharihari.

\section{DAFTAR PUSTAKA}

Mendra, I. W., \& Wiriantari, F. 2016. Perubahan Spasial Permukiman Tradisional di Desa Adat Tenganan Pegringsingan Bali. Jurnal Anala, 1(15), 73-97.

Iskandar, J. 2016. Etnobiologi dan Keragaman Budaya di Indonesia. UMBARA: Indomesian Journal of Anthropologi, 1(1), 25-41.

Sumunar, D. R. S., Suparmini, \& Setyawati, S, 2013. "Kearifan Lokal Masyarakat Baduy dalam Pengelolaan dan Pembagian Tata Ruang". Dalam 
Proseeding Seminar Nasional dalam rangka Dies Natalis Universitas Negeri Yogyakarta ke 49. Yogyakarta: Lembaga Penelitian dan Pengabdian Masyarakat UNY

Suryadarma, I. G. P. 2016. "Peran Hutan Masyarakat Adat dalam Menjaga Stabilitas Iklim Satu Kajian Perspektif Deep Ecology (Kasus Masyarakat Desa Adat Tenganan Bali). Dalam Proseeding Seminar Nasional
Peranan Konservasi Flora Indonesia dalam Mengatasi Dampak Pemanasan Global diselenggarakan oleh Kebun Raya "Eka Karya" Bali - LIPI.

Wiratno, Indriyo, D., Syarifudin, A., \& Kartikasari, A. 2001. Berkaca di Cermin Retak: Refleksi Konservasi dan Implikasi bagi Pengelolaan Taman Nasional. Jakarta: The Gibbon Foundation Indonesia, PILI-NGO Movement. 